https://doi.org/10.37208/tgn27201

\section{Native oyster (Ostrea edulis, L. 1758) on Great Cumbrae Island, Scotland}

\author{
P.G. Moore \\ 32 Marine Parade, Millport, Isle of Cumbrae \\ KA28 0EF \\ E-mail: p.geoff.moore@gmail.com
}

On 31st March 2019 I came across an isolated, living specimen of the native oyster (Ostrea edulis) at Ballochmartin Bay, Great Cumbrae Island (NS570182) (Fig. 1), which, after being photographed, was rapidly replaced in situ. I record this observation since in 40 or more years of taking student classes onto local beaches, I can recall only one other time (date unrecorded) that another live oyster was previously found on the same beach.

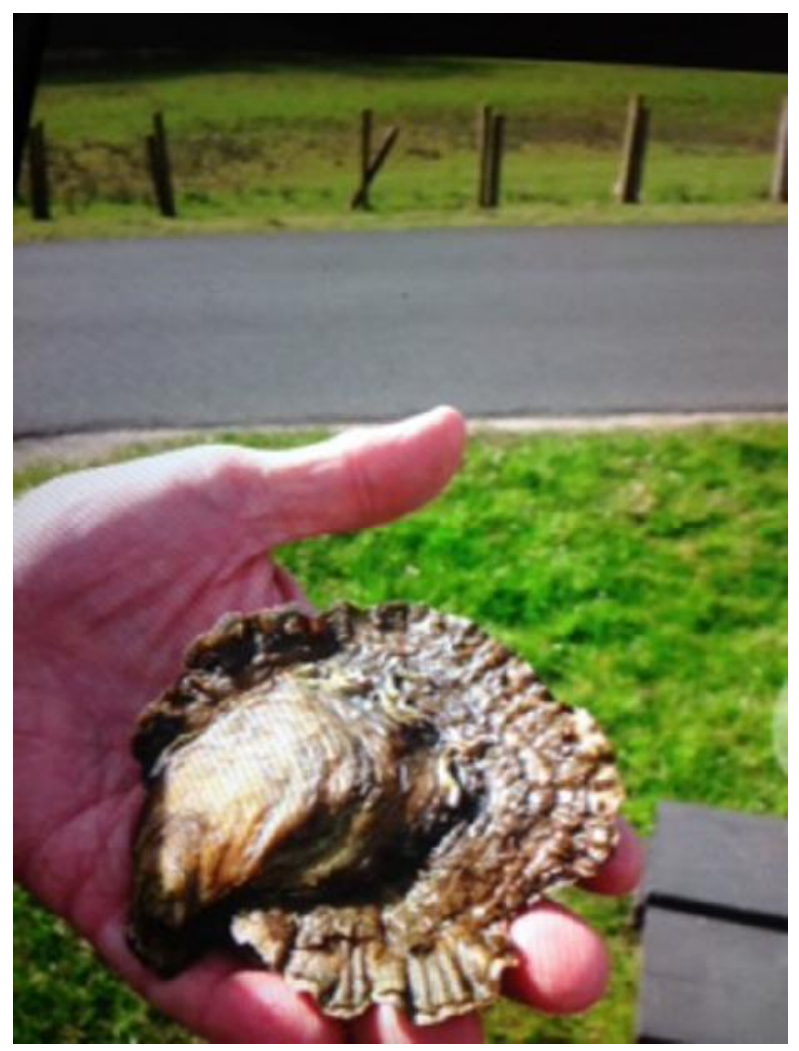

Fig. 1. A live oyster (Ostrea edulis) at Ballochmartin Bay, Great Cumbrae, Scotland, 31st March 2019. (Photo: J. Moore)

Allen (1962) reported that, except for Loch Ryan, in the Clyde Sea Area the species was scarce, represented by only remnants of cultivated oyster beds, among which he mentioned "Balloch Bay", likely referring to Ballochmartin Bay. In Chapter XIII of Millport and the Cumbraes (Campbell, 1975), which I contributed to,
I noted the following: "Oysters, once introduced in Balloch Bay, are now conspicuous by their absence". Dr Richard B. Pike began research on oysters from Millport in 1946, primarily in two arms of Loch Sween (Kyle Scotnish and Linne Mhuirich) but also at Easdale Quarry (Argyll). That work was continued by Dr Robin H. Millar. In May 1950 a large outdoor reinforced concrete tank was built for oyster research across the road from the then Scottish Marine Biological Association's Marine Station and in 1961 the ex-naval buildings at Keppel Point were fitted out as an oyster hatchery for Dr Michael Droop (Marshall, 1987). However, I can find no mention, in any of the Annual Reports of the Scottish Marine Biological Association from 1946 up to 1970, of Ballochmartin Bay being a deliberate oyster laying site, and so the history of any "cultivated oyster bed" there must be distant.

Times have changed markedly since Macdonald (1857) could comment glibly: "Passing Balloch Bay, where a board of oysters may be procured at certain states of the tide". That casual comment suggests that in the 19th century Ballochmartin Bay supported a natural bed of native oysters. My latest finding calls to mind another recent report of a find of "extinct" oysters (two live individuals) in the Firth of Forth, beds that once supported a huge fishery (Anonymous, 2009). Presumably what we witness on Cumbrae today is another historic example of a native oyster bed overexploited to effective extinction. The native oyster formed part of Scottish Natural Heritage's Species Action Framework, with an objective to attempt restoration of oyster populations in areas where they were previously abundant (Gaywood et al., 2016). Might efforts to restore Firth of Forth populations also be applicable to Cumbrae?

There is considerable interest Europe-wide at present in the restoration of native oyster beds, as witness the Native Oyster Restoration Alliance (NORA) (see https://noraeurope.eu) and a research project is currently being run by Heriot-Watt University in conjunction with The Marine Conservation Society and Glenmorangie Distillery with a view to the restoration of native oysters in the Dornoch Firth, Highland (D. Donnan, pers. comm.). The native oyster is a Priority Marine Feature under the National Marine Plan such that no damage may be done to a native oyster bed. There are anecdotal reports that small pockets of native oysters might exist at the head of Loch Riddon and Loch Striven, Argyll (A. Forbes, pers. comm.). Indeed it seems likely that all the Clyde sea lochs might once have held native oyster populations at their heads. Such populations are known from Campbeltown Loch, Loch Tarbert and possibly Loch Fyne (all Argyll), although the last requires confirmation (D. Donnan, pers. comm.).

Intriguing questions remain. How old might the Ballochmartin Bay 2019 individual be? Native oysters 
may live up to 15 years, although six years is more usual (University Marine Biological Station Millport, 2007). Whence might any remaining local spawning stock originate? David Donnan informed me that he found a small population (40 or so individuals) of native oysters living on Southannan sands (North Ayrshire), on the mainland opposite to Cumbrae, that were associated with slightly elevated patches of mussel (Mytilus edulis) beds, and that the population contained individuals of a range of sizes. This then may be the origin of a larva reaching Ballochmartin Bay on Cumbrae, where a range of shelly ground provides potential cultch, the material comprising oyster grounds.

Pacific oysters (Crassostrea gigas), brought in as juveniles, are reared commercially at Portencross on the adjacent mainland but are non-spawning and held in enclosed tanks with escapees being highly unlikely (A. Forbes, pers. comm.).

\section{ACKNOWLEDGEMENTS}

I thank Alan Forbes (Cumbrae Oysters Ltd.) and David Donnan (Scottish Natural Heritage) for their helpful comments.

\section{REFERENCES}

Anonymous (2009). Researcher finds 'extinct' oysters in Firth of Forth. Fish Farmer, 6th November 2009.

Allen, J.A. (1962). Mollusca. The Fauna of the Clyde Sea Area. Scottish Marine Biological Association, Millport.

Campbell, J.R.D. (1975). Millport and the Cumbraes: A History and Guide. Cunninghame District Council, Irvine.

Gaywood, M.J., Boon, P.J., Thompson, D.B.A. \& Strachan, I.M. (Editors) (2016). Species Action Framework Handbook. Scottish Natural Heritage, Battleby, Perth.

https://www.nature.scot/species-action-frameworkhandbook

Macdonald, H. (1857). Days at the Coast: A Series of Sketches Descriptive of the Frith of Clyde - its Watering Places, its Scenery, and its Associations. Thomas Murray \& Son, Glasgow.

Marshall, S.M. (1987). An Account of the Marine Station at Millport. Occasional Publication No. 4. University Marine Biological Station Millport, Millport.

University Marine Biological Station Millport (2007). Conservation of the native oyster Ostrea edulis in Scotland. Scottish Natural Heritage, Commissioned Report No. 251. (ROAME No. FO2AA408). https//www.nature.scot/plants-animals-and-fungi/in vertebrates/marine-invertebrates/native-oyster Accessed 1st April 2019. 